\title{
Long-term dynamies in nutrients, chlorophyll $a$ and water quality parameters in the Lagoon of Venice
}

\author{
Francesco Acri, Federica Braga, Fabrizio Bernardi Aubry \\ ISMAR - CNR, Arsenale Tesa 104, Castello 2737/F, 30122 Venezia, Italy. \\ (FA) E-mail: francesco.acri@ve.ismar.cnr.it. ORCID iD: https://orcid.org/0000-0002-5405-224X \\ (FB) E-mail: federica.braga@ @e.ismar.cnr.it. ORCID iD: https://orcid.org/0000-0002-4131-9080 \\ (FBA) (Corresponding author) E-mail: fabrizio.bernardi@ ve.ismar.cnr.it. ORCID iD: https://orcid.org/0000-0003-0417-8597
}

\begin{abstract}
Summary: Since 1997, CNR-ISMAR has been collecting monthly hydrochemical and phytoplankton data in the northern and central basins of the Lagoon of Venice. The data have been part of the International Long-Term Ecosystem Research (LTER) database since 2007, helping to fill a gap in lagoon environmental studies. Analysing our time series (1998-2017), we were able to observe a rise in water temperature due to climate trends, a reduction in trophic status mainly due to the lower input of inorganic dissolved nitrogen nutrients and an increase in transparency and dissolved oxygen related to the increased biomass of macrophytes (macroalgae and seagrasses). Finally, a reduction in phytoplankton biomass and an accompanying increase in seagrass and macroalgal cover were observed. Present and future studies will help to evaluate the ways in which the Lagoon of Venice ecosystem responds to anthropogenic pressures and global climate change.
\end{abstract}

Keywords: nutrients; phytoplankton biomass; multiannual variation; water quality; Lagoon of Venice.

Dinámica temporal de nutrientes, clorofila $a$ y parámetros de calidad del agua en la Laguna de Venecia

Resumen: Desde 1997, el CNR ISMAR ha recopilado datos mensuales de hidroquímica y fitoplancton en las zonas del norte y centro de la Laguna de Venecia. Desde el 2007 los datos hacen parte de la base de datos LTER (International Long-Term Ecosystem Research), ayudando a llenar la falta de datos en los estudios ambientales de la Laguna. Analizando nuestra serie histórica (1998-2017), pudimos observar un aumento de la temperatura del agua debido a las tendencias climáticas, una reducción del estado trófico debido principalmente al menor suministro de nutrientes inorgánicos de nitrógeno disuelto y un aumento de la transparencia y del oxí́geno disuelto relacionado al aumento de la biomasa de macrófitas (macroalgas y fanerógamas). Por último, se observó una reducción de la biomasa del fitoplancton y al mismo tiempo un aumento de fanerógamas y macroalgas. Los actuales y futuros estudios ayudarán a evaluar las formas en el cual el ecosistema de la Laguna de Venecia responderá a las presiones antropogénicas y al cambio climático global.

Palabras clave: nutrientes; biomasa fitoplanctónica; variación plurianual; calidad del agua; Laguna de Venecia.

Citation/Como citar este artículo: Acri F., Braga F., Bernardi Aubry F. 2020. Long-term dynamics in nutrients, chlorophyll $\mathrm{a}$ and water quality parameters in the Lagoon of Venice. Sci. Mar. 84(3): 215-225. https://doi.org/10.3989/scimar.05022.30A

Editor: M. Estrada.

Received: December 5, 2019. Accepted: May 15, 2020. Published: June 5, 2020.

Copyright: (c) 2020 CSIC. This is an open-access article distributed under the terms of the Creative Commons Attribution 4.0 International (CC BY 4.0) License.

\section{INTRODUCTION}

Until about 20 years ago, budgetary constraints and a short-term approach to management led to an emphasis on research and monitoring projects of short duration, with results that were of immediate use in decision-making processes. In addition, given that in most academic institutions the professional advancement of researchers was (and is) dependent on their publication records, investigators tended to avoid long-term com- mitments to data collection that had no obvious goals in terms of testable hypotheses and subsequent papers to be published in primary journals (Wolfe et al. 1987). For these reasons, there was a shortage of monitoring and research programmes that entailed sampling from the same sites over long periods in accordance with comparable analytical methods. However, researchers have long been aware of the importance of long-term studies in ecology for the creation of testable hypotheses regarding environmental changes (Franklin 1989, 
Coull 1985, Wolfe et al. 1987) and comparison of current environmental quality with that of the past. In the last few decades, the importance of maintaining long-term data series and the challenges this involves have been addressed with the creation of Long-Term Ecosystem Research (LTER) sites and networks, now well-established at the international (LTER-International), regional (LTER- Europe) and national (e.g. LTER-Italy) levels (Mirtl et al. 2018). What makes LTER networks unique is that they make it possible to look at the bigger ecological picture, enhancing knowledge by enabling the innovative combination of different types of information and the integration of long-term data series with the large-scale analysis of patterns (Haase et al. 2016, 2018).

The Lagoon of Venice (LoV) is probably one of the most extensively studied ecosystems in the world (Tagliapietra et al. 2011). However, until recently, most of the research was concerned with specific processes or was conducted in response to environmental emergencies (Solidoro et al. 2004). Moreover, data were collected by separate local agencies in accordance with different methodological approaches, meaning that they were not always comparable.

Since 1997, CNR-ISMAR has been collecting longterm hydrological and biological data in the LoV (Bianchi et al. 2003, Bernardi Aubry et al. 2013). Moreover, since 2007 the LoV has been part of LTER-Italy, LTER-Europe and LTER-International (Bertoni 2012). In recent years, multiannual monitoring programmes have been implemented at regular intervals by the Italian Regional Environmental Protection Agencies (ARPAs) in fulfilment of the requirements of the European Water Framework Directive (WFD 2000/60/EC; Borja 2005, European Union 2000). The main concern of the WFD, which came into effect in 2000, is the assessment of the ecological status of water bodies (coastal waters, transitional waters, inland surface waters and ground waters) with a view to their protection, improvement and sustainable use.

Nutrient levels and phytoplankton biomass have also been included as water quality indicators for assessing the evolution of the trophic state of transitional waters, which is a key ecological issue and has profound implications for environmental management. From the 1950s to the 1980s, as a result of the growing use of fertilizers in the farmland surrounding the LoV and the increasingly industrial character of its drainage basin, nitrogen inputs to the lagoon doubled (from about $4500 \mathrm{t} \mathrm{yr}^{-1}$ to $9000 \mathrm{t} \mathrm{yr}^{-1}$; Solidoro et al. 2010) and phosphorus inputs increased nearly threefold (from about $500 \mathrm{t} \mathrm{yr}^{-1}$ to $1300 \mathrm{t} \mathrm{yr}^{-1}$; Solidoro et al. 2010). The construction of wastewater treatment plants and the total ban on the use of phosphorus in the manufacturing of detergents in 1989 resulted in phosphorus inputs falling to less than half the levels recorded in 1950 , with further decreases over the last 20 years. In contrast, a fall in nitrogen loads has only been observed since the 1990s. This has been driven by a number of factors, including the introduction of nitrification/denitrification processes in the major treatment plants, the closure of fertilizer factories and the adoption of bet- ter fertilization practices in agriculture (Solidoro et al. 2010). Consequently, nitrogen levels have returned to 1950 levels. As for phytoplankton biomass, after peaking in the 1970s (190 $\mu \mathrm{g} \mathrm{L}^{-1}$ in 1978), chlorophyll $a$ concentrations fell to $<25 \mu \mathrm{g} \mathrm{L}^{-1}$ in the 1980 s. Despite a small increase from 2000 to 2003, even lower values were recorded in subsequent years (Solidoro et al. 2010, Bernardi Aubry et al. 2013).

The aim of this paper is to document the analysis of some of the vast amount of hydrological and biological data collected on transparency, temperature, salinity, dissolved oxygen, inorganic dissolved nutrients and chlorophyll $a$ in the framework of LTER-Italy. Here, we present some findings emerging from the statistical analysis of a twenty-year (1998-2017) dataset based on the LoV, focusing on the evolution of trophic state and phytoplankton biomass. It is not the purpose of this article to deal with spatial and seasonal variability, already discussed in previous articles (Bianchi et al. 2003, Bernardi Aubry et al. 2013); our main aim is to identify significant trends in the LoV by considering multiannual series.

\section{MATERIALS AND METHODS}

\section{Study area}

The LoV (Fig. 1) is a large $\left(550 \mathrm{~km}^{2}\right)$ Mediterranean lagoon located in the northern Adriatic Sea. Microtidal and polyhaline, it is classified as a transitional water body (European Union, 2000). The largest wetland in the Mediterranean (Poggioli 2008), the lagoon forms a sensitive ecosystem surrounded by densely inhabited and industrial areas and is also subject to strong pressure from tourism, fisheries and aquaculture. The average depth is $1 \mathrm{~m}$. Morphologically, the lagoon bed is characterized by the presence of extensive shallow areas and a network of channels of varying depth (5-10 $\mathrm{m})$. Separating the lagoon from the Adriatic Sea is a series of sandbars, interrupted by three inlets that enable water exchange during tidal cycles, whose amplitude is usually about $100 \mathrm{~cm}$ although it can reach $150 \mathrm{~cm}$. Tide, wind and topography combine to produce water residence times ranging from a few days near the inlets to one month in the landward areas (Umgiesser et al. 2014, Ghezzo et al. 2015). The average annual freshwater discharge from the lagoon's 12 main tributaries is about $35 \mathrm{~m}^{3} \mathrm{~s}^{-1}$, with seasonal peaks in spring and autumn. Recent years have seen a resurgence of aquatic angiosperms and sensitive macroalgae, especially in the lagoon's central and northern basins (Sfriso and Buosi 2018). However, phytoplankton is still the main primary producer across much of the lagoon (Acri et al. 2004, Sfriso et al. 2005, Bernardi Aubry et al. 2013).

Overall, the five sampling stations in this study (Fig. 1) are representative of the natural and anthropogenic environmental variability of the lagoon's northern and central basins. The interplay of freshwater and marine inputs (Cucco and Umgiesser 2006, Solidoro et al. 2004) is made even more complex by the impact of anthropogenic factors (Bianchi et al. 2003). The interactions between the adjacent marine waters, riverine 


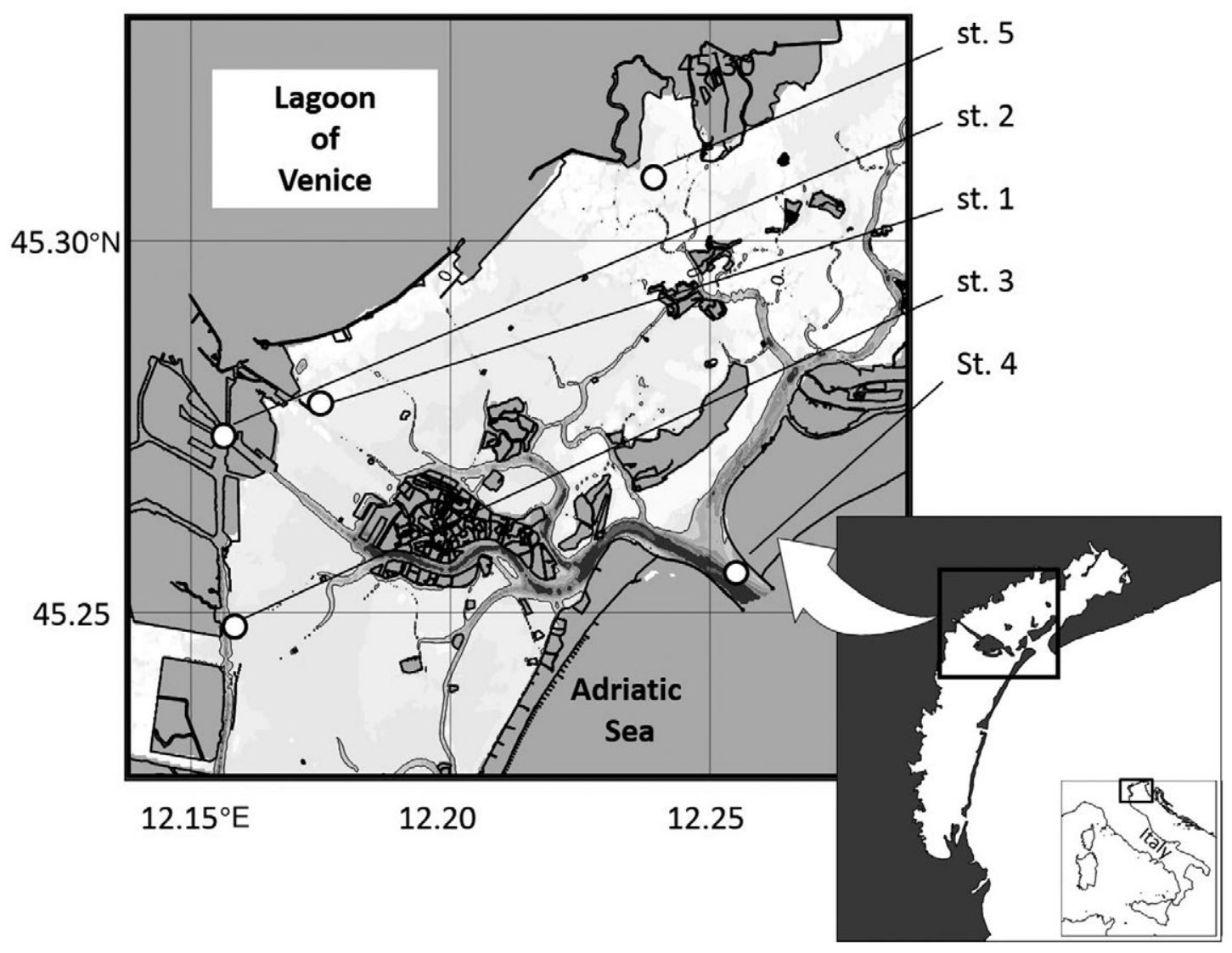

Fig. 1. - The Lagoon of Venice and the five sampling stations used for long-term data gathering.

inputs and benthic-pelagic coupling result in strong spatial environmental variation (Bernardi Aubry et al. 2013). Furthermore, the five sampling stations were chosen so that each one was representative of a specific type of lagoon habitat (Alberighi et al. 1992, Socal et al. 1999, Bianchi et al. 2003). At the beginning of the long-term study in 1997, in the area identified for sampling, the main primary producer was phytoplankton (Sfriso et al. 2005, Bernardi Aubry et al. 2013). The highest inorganic dissolved nutrient concentrations and phytoplankton biomass and the lowest salinity were found at stations influenced by urban or industrial waste (St. 1 and St. 2), and the highest water temperature was found in the area affected by heat emissions from the Fusina power plant (St. 3). Relatively low nutrient concentrations were observed at the station near the lagoon's northernmost inlet, which is under the direct influence of Adriatic coastal waters (St. 4). Station 5 is located in a marshy area, a typical lagoon environment.

\section{Sampling process and laboratory analysis}

Samples were collected each month from January 1998 to December 2017 at a depth of $0.5 \mathrm{~m}$ at neap tide, in order to minimize the effect of tidal hydrodynamics. The following parameters were measured: transparency, with a Secchi disc; temperature, using a bucket thermometer; salinity with a Guildline Autosal
8400B until 2011 and thereafter with a multiparametric Idronaut mod. 801 and Sea-Bird SBE 19 plus; dissolved oxygen, in accordance with Winkler's method (Strickland and Parsons 1972); inorganic dissolved nutrients including nitrogen as ammonium $\left(\mathrm{N}_{-} \mathrm{NH}_{4}\right)$, nitrites $\left(\mathrm{N}-\mathrm{NO}_{2}\right)$ and nitrates $\left(\mathrm{N}-\mathrm{NO}_{3}\right)$, and phosphorus as orthophosphates $\left(\mathrm{P}-\mathrm{PO}_{4}\right)$. Nutrients were analysed with a Systea-Alliance Continuous Flow Analyser until 2007 and thereafter with a Systea EasyChem Plus, in accordance with the methods indicated by Grasshoff et al. (1983). Chlorophyll $a$ samples were filtered on board and the filters were kept at $-20^{\circ} \mathrm{C}$ until they were analysed in the laboratory. Chlorophyll $a$ concentrations, corrected for phaeopigments, were determined fluorometrically (Holm-Hansen et al. 1965) in 90\% acetone extracts with a Perkin Elmer LS5B spectrofluorometer until 2010 and thereafter with a Turner Trilogy Laboratory Fluorometer. Analytical quality was assessed via participation in the Quality Assurance of Information for Marine Environmental Monitoring in Europe (QUASIMEME; http://www.quasimeme.org) international laboratory proficiency-testing programme.

\section{Satellite images}

Four Landsat satellite images, two from Thematic Mapper (TM) taken in 1998 and 1999 and two from Operational Land Imager (OLI) taken in 2016 and 2017, were used for mapping the retrospective 


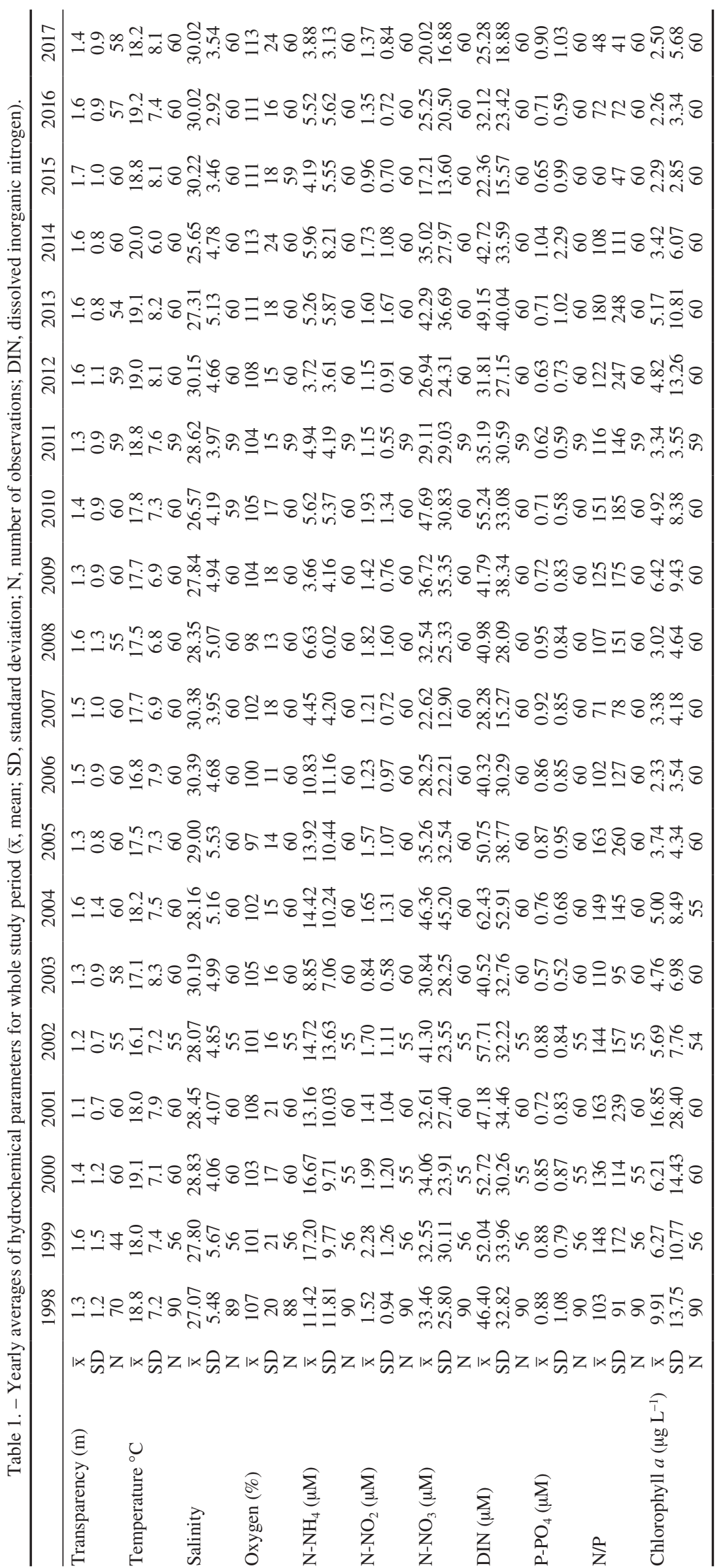

macrophyte coverage (seagrasses and macroalgae) in the central and northern lagoon. A common imageprocessing chain was applied to both TM and OLI data (see Giardino et al. 2012, 2014 and Ghirardi et al. 2019, and references herein), parametrized with in situ dataset, in order to obtain macrophyte maps.

\section{Statistical analyses}

Interannual trends were analysed by applying seasonal Kendall- $\tau$ nonparametric analysis to the whole data set. This analysis determines the direction of trends ( + or - ), goodness of fit $(\tau)$ and the statistical significance of fit (Boyer et al. 1999, Hirsch et al. 1991). The rate of change of each variable is quantified by the seasonal Kendall slope, i.e. the median changeper-year (over all pairs of years for each month) of each parameter (Theil 1950, Sen 1968). Principal component analysis (PCA R-mode) was used to identify relations between environmental variables, displaying groups of observations (years) in a two-dimensional space. Data were averaged to yearly values in order to highlight annual variations; missing values were replaced by the mean of the variables. In order to compare the groups of samples (years) clustered by PCA, we performed a MannWhitney test, which is the non-parametric alternative to the independent sample t-test. PCA and the MannWhitney test were performed using XLSTAT 2018.1, while seasonal Kendall- $\tau$ was measured with WQ2 software (release 2.0, EQMetric, LLC and Virginia Tech Intellectual Properties Inc.). To test the shift in the mean values of the whole dataset, a sequential t-test of regime shift was performed in accordance with Rodionov (2004). The normality of data was verified for both PCA R-mode and the regime shift test using the Kolmogorov-Smirnov test.

\section{RESULTS}

\section{Interannual variability}

In order to enable an overview of interannual variability, the data were averaged. They are summarized in Table 1 and Figure 2. The annual average water temperature oscil- 

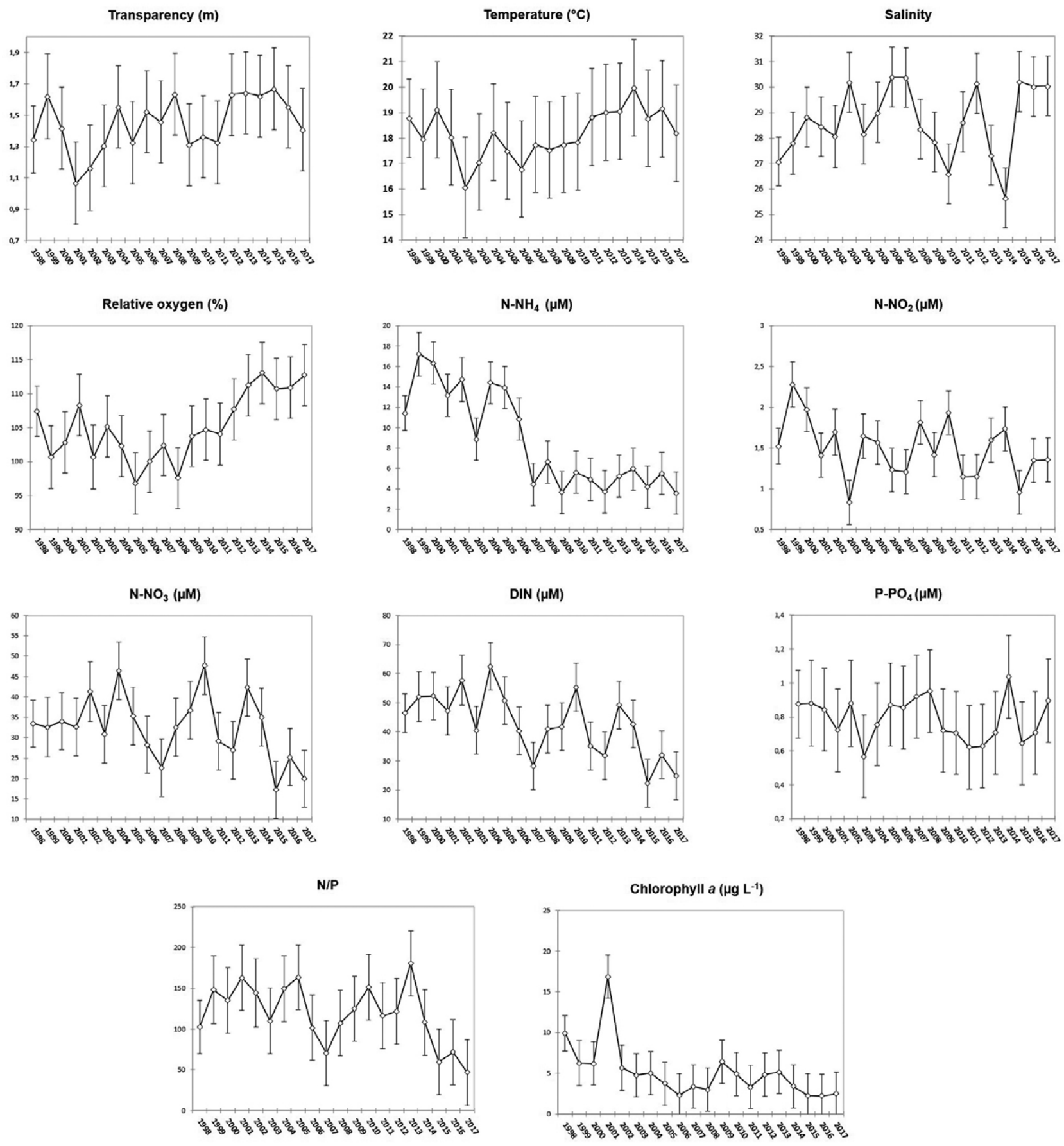

Fig. 2. - Hydrochemical parameters: yearly averages and confidence limits.

lated between $16.1^{\circ} \mathrm{C}$ and $20.0^{\circ} \mathrm{C}$, values measured respectively in 2002 and 2014. The lowest mean annual salinity was observed in 2010 and 2014 (26.57 and 25.65 respectively), which were the two rainiest years, while the dry years $(2003,2006,2007$ and 2015; Fig. 3) saw the highest average salinity (respectively $30.19,30.39,30.38$ and 30.22). The mean annual transparency was always above $1.0 \mathrm{~m}$, with a maximum of $1.7 \mathrm{~m}$ measured in 2015. Mean relative oxygenation, which never fell below 97\%, was highest in recent years (2012-2017), which all had values above $110 \%$, with a maximum of $113 \%$ in 2014 and 2017. In the period 1998-2006, average ammonium $\left(\mathrm{N}-\mathrm{NH}_{4}\right)$ values were in the range 8.85-17.20 $\mu \mathrm{M}$; they subsequently fell sharply, with mean annual concentrations of 3.66 $\mu \mathrm{M}$ to $6.63 \mu \mathrm{M}$ for the rest of the period. The oxidized forms of nitrogen $\left(\mathrm{N}-\mathrm{NO}_{2}\right.$ and $\left.\mathrm{N}-\mathrm{NO}_{3}\right)$ followed a more variable trend. In recent years (2015-2017), mean nitrate concentrations were lower than previously, with the lowest value seen in $2015(17.21 \mu \mathrm{M})$. Dissolved inorganic nitrogen (as the sum of $\mathrm{N}-\mathrm{NH}_{4}, \mathrm{~N}-\mathrm{NO}_{2}$ and $\mathrm{N}-\mathrm{NO}_{3}$ ) followed a trend similar to that of nitrates, due to the predominance of the latter over the other two. The mean annual concentrations of orthophosphates 


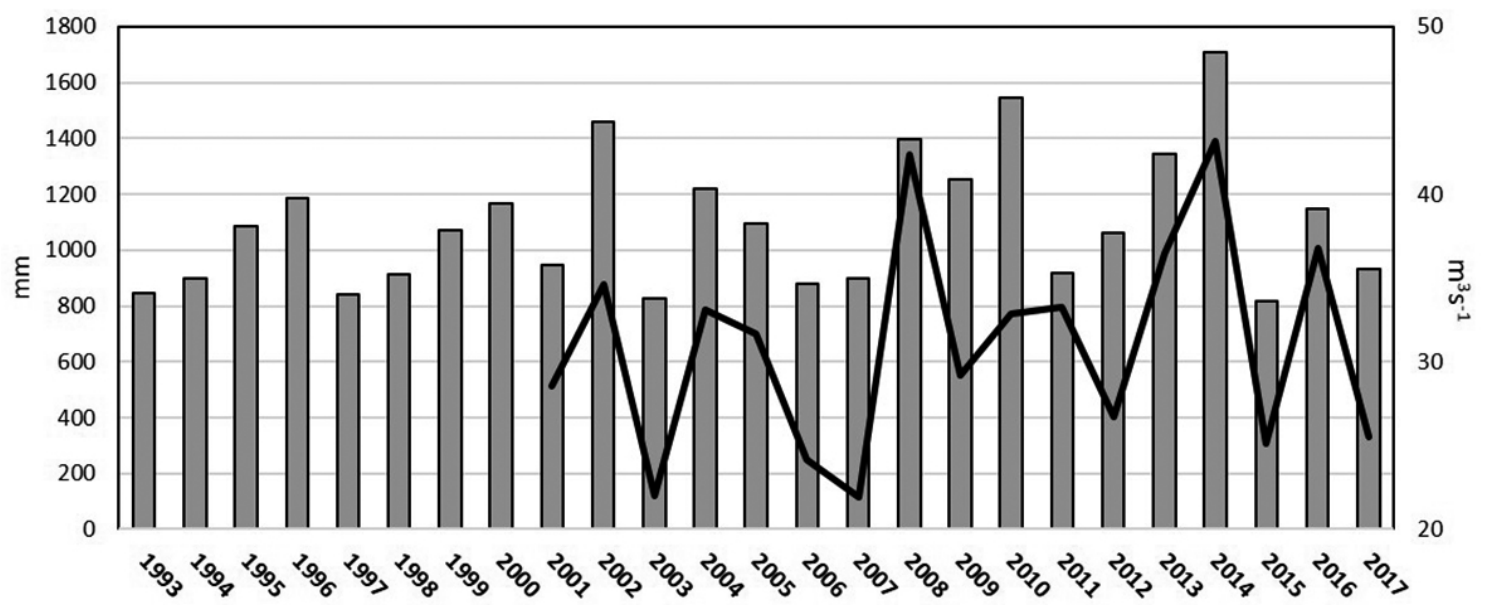

Fig. 3. - Mean annual rainfall (bars; $\mathrm{mm}$ ) in the Veneto Region (1993-2017) and mean annual river discharge from drainage basin (line; $\mathrm{m}^{3}$ $\mathrm{s}^{-1}$ ) of the LoV (2001-2017). Data from Regione Veneto-ARPAV (Agency for the Protection of the Veneto Environment).

(P-PO $)_{4}$ oscillated between 0.57 and $1.04 \mu \mathrm{M}$, values recorded respectively in 2003 and 2014. Low levels of inorganic phosphorus were responsible for the high N/P ratios, which in the period 2015-2017 were lower than in the previous years, due to the decrease in inorganic nitrogen. Mean phytoplankton biomass (as chlorophyll a) was always below $10 \mu \mathrm{g} \mathrm{L}^{-1}$, except in 2001 when an average of $16.85 \mu \mathrm{g} \mathrm{L}^{-1}$ was recorded.

\section{Statistical analysis of trends}

In order to highlight any significant interannual trends, we applied the Kendall- $\tau$ test to the hydrochemical parameters over the 20 years considered (Table 2). With regard to the hydrological parameters, a statistically significant increase was detected for transparency, temperature and relative oxygen, while for salinity the increase was not significant. Ammonium, nitrates and dissolved inorganic nitrogen decreased significantly, but nitrites and orthophosphates did not. The fall in the $\mathrm{N} / \mathrm{P}$ ratio was significant, because of the large decrease in inorganic nitrogen. Phytoplankton biomass, as chlorophyll $a$, also dropped significantly.

Table 2. - Seasonal Kendall test of the hydrochemical parameters and rainfall data: $\tau$ values $(\tau)$, significance of trend $(p)$, seasonal Kendall slope estimates (SE) in units $\mathrm{yr}^{-1}$ and number of observations (N) are shown (NS, not significant). Rainfall data from Regione Veneto-ARPAV (Agency for the Protection of the Veneto Environment). DIN, dissolved inorganic nitrogen.

\begin{tabular}{|c|c|c|c|c|}
\hline & \multicolumn{4}{|c|}{$1998-2017$} \\
\hline & $\tau$ & $\mathrm{p}$ & SE & $\mathrm{N}$ \\
\hline Transparency (m) & 0.25 & $<0.01$ & 0.02 & 1169 \\
\hline Temperature $\left({ }^{\circ} \mathrm{C}\right)$ & 0.15 & $<0.01$ & 0.08 & 1220 \\
\hline Salinity & 0.11 & NS & 0.05 & 1218 \\
\hline Relative oxygen (\%) & 0.18 & $<0.01$ & 0.46 & 1217 \\
\hline $\mathrm{N}-\mathrm{NH}_{4}(\mu \mathrm{M})$ & -0.48 & $<0.01$ & -0.54 & 1215 \\
\hline $\mathrm{N}-\mathrm{NO}_{2}(\mu \mathrm{M})$ & -0.15 & NS & -0.02 & 1215 \\
\hline $\mathrm{N}-\mathrm{NO}_{3}(\mu \mathrm{M})$ & -0.22 & $<0.05$ & -0.58 & 1215 \\
\hline $\mathrm{DIN}(\mu \mathrm{M})$ & -0.34 & $<0.01$ & -1.26 & 1215 \\
\hline $\mathrm{P}_{-} \mathrm{PO}_{4}(\mu \mathrm{M})$ & -0.10 & NS & -0.01 & 1215 \\
\hline $\mathrm{N} / \mathrm{P}$ & -0.21 & $<0.05$ & -1.30 & 1215 \\
\hline Chlorophyll $a\left(\mu \mathrm{g} \mathrm{L}^{-1}\right)$ & -0.27 & $<0.01$ & -0.05 & 1214 \\
\hline Rainfall (mm) & 0.02 & NS & 0.29 & 3996 \\
\hline
\end{tabular}

\section{Regime shift detection}

A regime shift is what happens when an ecosystem undergoes rapid reorganization from one relatively stable state to another. In order to verify the existence of years marking the start of new regimes in the LoV, we applied the regime shift detection method to the hydrochemical parameters. An increase marking a significant shift was observed in the period 2010-2011 for water temperature and in 2011-2012 for transparency and relative oxygen (Fig. 4). Finally, a sharp decrease in ammonium was also noted after 2006. No significant shift was found for the other parameters.

\section{Differences between groups of years}

Focusing on the relations between environmental parameters and groups of samples, PCA R-mode (Fig. 5) was performed. In order to highlight annual variations, the data were averaged into yearly values. The bi-plot of the first two PCA components highlighted the similarities/dissimilarities between the sampling periods, explaining about $58 \%$ of the total variance. The bi-plot showed the following:

- nutrients and chlorophyll $a$ both have positive loadings on component 1 and were positively correlated with each other;

- salinity has a negative influence on component 1 and is negatively correlated with nutrients and chlorophyll $a$. This means that the first principal component is related to river discharge and rainfall and that lower salinity values generally correspond to higher nutrient concentrations. The first and second quadrants contain years with an average rainfall greater than $1200 \mathrm{~mm}$ (2004, 2008, 2010, 2013 and 2014); the third quadrant contains dry years (2003, 2006 and 2007; Fig. 3);

- temperature, transparency and relative oxygen have positive loadings on component 2 and are positively correlated;

- the group of years from 2012 to 2017 , characterized by a significant regime shift regarding temperature, 
Trasparency (m)

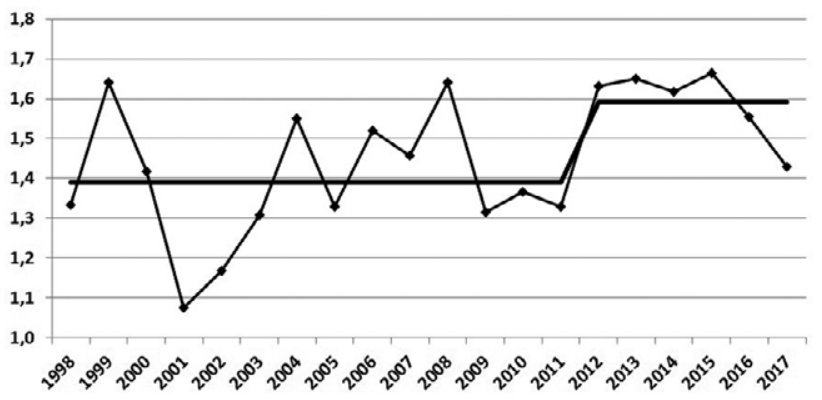

Relative oxygen (\%)

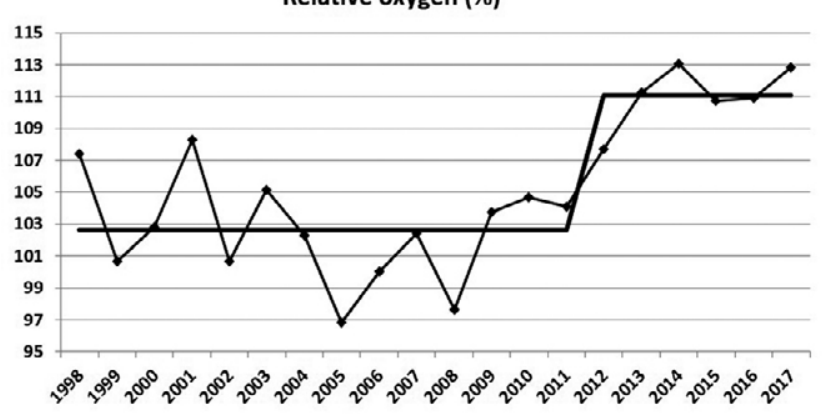

Temperature $\left({ }^{\circ} \mathrm{C}\right)$

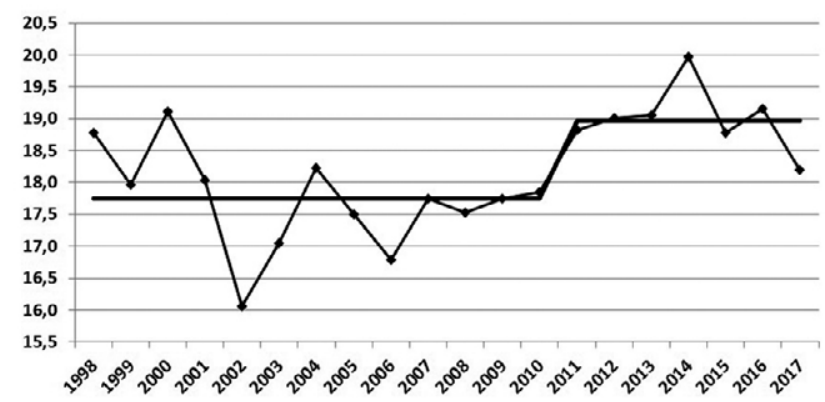

$\mathrm{N}-\mathrm{NH}_{4}(\mu \mathrm{M})$

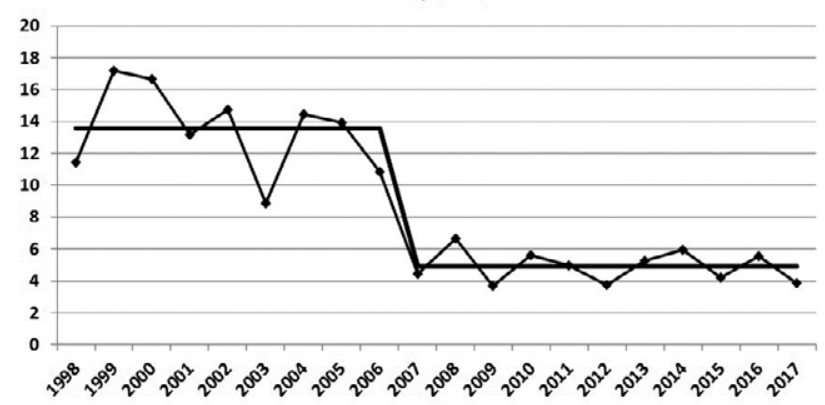

Fig. 4. - Time series of mean annual transparency, temperature, relative oxygen and ammonium in the sampling area. The thick line represents the stepwise trend showing the regime shifts.

Biplot (axes F1 and F2: $58.09 \%$ )

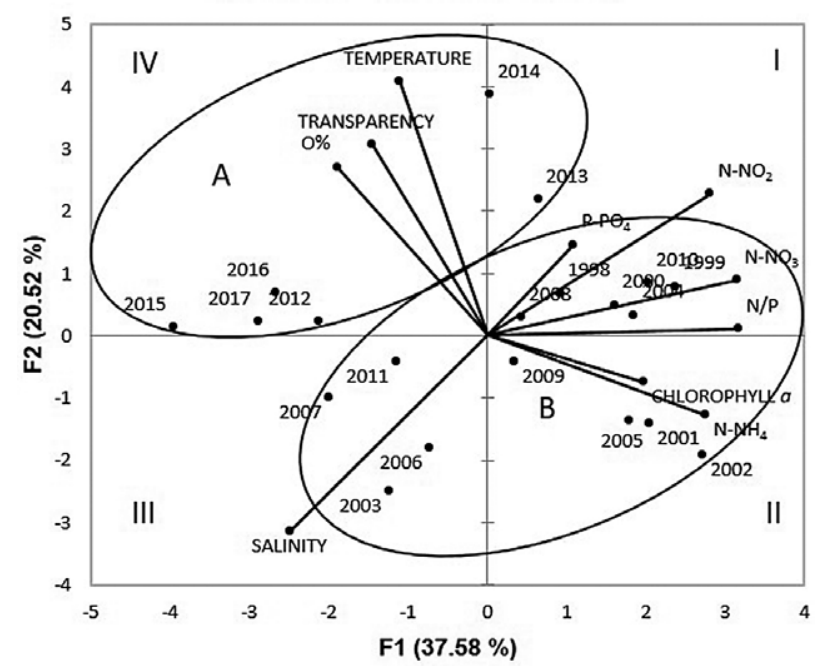

Fig. 5. - Principal component analysis (PCA R-mode): the space is divided into four quadrants (I-IV) to facilitate interpretation; cluster A, years 2012-2017; cluster B, years 1998-2011. Data are shown as annual averages.

transparency and relative oxygen (Fig. 4), can be seen as forming a cluster (A; quadrants I and IV; Fig. 5);

- the previous years (1998-2011, quadrants I, II and III) may be seen as forming another cluster (B; Fig 5).

Comparison of the periods 1998-2011 (cluster A) and 2012-2017 (cluster B) by means of the MannWhitney test (Table 3) showed that transparency, temperature and relative oxygen were significantly higher in 2012-2017 than in 1998-2011, while the increase in salinity was not significant. Regarding nutrient levels, nitrogen as ammonium, nitrites, nitrates and dissolved inorganic nitrogen were higher in 1998-2011 than in 2012-2017, while no statistically significant trend was detected for orthophosphates. The N/P ratio was significantly higher in 1998-2011 than in 2012-2017. Chlorophyll $a$ concentrations were roughly twice as high in 1998-2011 as in 2012-2017.

\section{DISCUSSION}

Data series based on samplings performed at regular intervals across large lagoon areas for prolonged periods in accordance with shared methods are a uniquely useful resource that can be used to both generate and test hypotheses regarding the impact of environmental changes.

Over the last 20 years, the temperature of the lagoon waters has increased (Table 2). In addition, it has been shown (Amos et al. 2017) that the waters of the $\mathrm{LoV}$ are warming at a faster rate than both the global average and the adjacent sea. Specifically, the increase during winter months appears to be directly linked to tourism (University of Southampton 2012) as a result of the 'urban heat island effect', a microclimatic phenomenon occurring in correspondence with urban centres, in which the increased number of tourists leads to more human activities, more anthropogenic heat emissions, causing local overheating (Zhang and Wu 2015).

With regard to salinity, identifying long-term changes in the LoV is difficult. Precipitation patterns and the (far from even) ebb and flow of the tides result in wide variability that is unrelated to changes in the salinity of the water itself. The increase in this parameter shown by our data is not significant (Tables 2 and 3 ), in accordance with the steady-state condition of the LoV detected by Zirino et al. (2014). 
Table 3. - Mann-Whitney test of the hydrochemical parameters highlighting the differences between the periods 1998-2011 and 2012-2017 ( $\overline{\mathrm{x}}$, mean; SD, standard deviation; N, number of observations; $\mathrm{p}$, probability level; NS, not significant).

\begin{tabular}{|c|c|c|c|c|c|c|c|}
\hline & \multicolumn{3}{|c|}{$1998-2011$} & \multicolumn{3}{|c|}{$2012-2017$} & \multirow{2}{*}{$\begin{array}{c}\text { Mann-Whitney test } \\
\mathrm{p}\end{array}$} \\
\hline & $\overline{\mathrm{x}}$ & SD & $\mathrm{N}$ & $\overline{\mathrm{x}}$ & SD & $\mathrm{N}$ & \\
\hline Transparency (m) & 1.4 & 1.0 & 821 & 1.6 & 0.9 & 348 & $<0.01$ \\
\hline Temperature $\left({ }^{\circ} \mathrm{C}\right)$ & 17.8 & 7.4 & 860 & 19.0 & 7.6 & 360 & $<0.02$ \\
\hline Salinity & 28.51 & 4.91 & 858 & 28.90 & 4.50 & 360 & NS \\
\hline Relative oxygen $(\%)$ & 103 & 17 & 858 & 111 & 20 & 359 & $<0.01$ \\
\hline $\mathrm{N}-\mathrm{NH}_{4}(\mu \mathrm{M})$ & 10.41 & 10.01 & 855 & 4.76 & 5.61 & 360 & $<0.01$ \\
\hline $\mathrm{N}-\mathrm{NO}_{2}(\mu \mathrm{M})$ & 1.54 & 1.12 & 855 & 1.36 & 1.07 & 360 & $<0.01$ \\
\hline $\mathrm{N}-\mathrm{NO}_{3}(\mu \mathrm{M})$ & 34.47 & 29.35 & 855 & 27.79 & 25.83 & 360 & $<0.01$ \\
\hline $\mathrm{DIN}(\mu \mathrm{M})$ & 46.42 & 34.88 & 855 & 33.91 & 29.09 & 360 & $<0.01$ \\
\hline $\mathrm{P}-\mathrm{PO}_{4}(\mu \mathrm{M})$ & 0.80 & 0.82 & 855 & 0.77 & 1.24 & 360 & NS \\
\hline N/P & 127 & 160 & 855 & 98 & 160 & 360 & $<0.01$ \\
\hline Chlorophyll $a\left(\mu \mathrm{g} \mathrm{L}^{-1}\right)$ & 6.00 & 11.78 & 854 & 3.41 & 8.00 & 360 & $<0.01$ \\
\hline
\end{tabular}
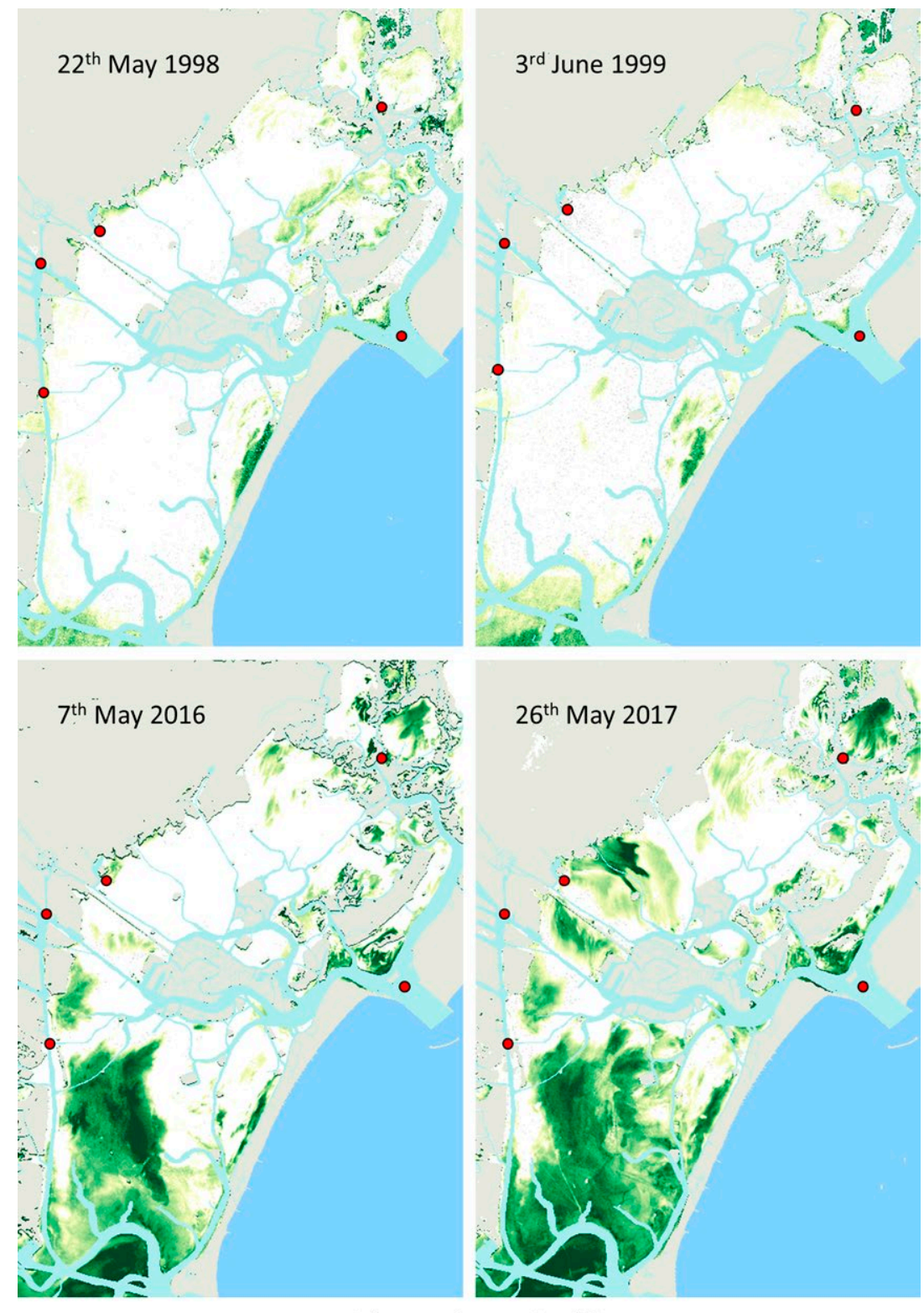

Submerged vegetation $(\%)$

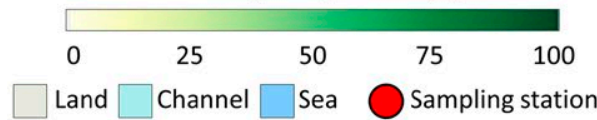

Fig. 6. - Spatial distribution of macrophyte coverage (seagrasses and macroalgae) in the central and northern lagoon in spring (22 May 1998, 3 June 1999, 7 May 2016 and 26 May 2017). The maps were derived from Landsat satellite images and processed as reported in Giardino et al. (2014) and Ghirardi et al. (2019). 


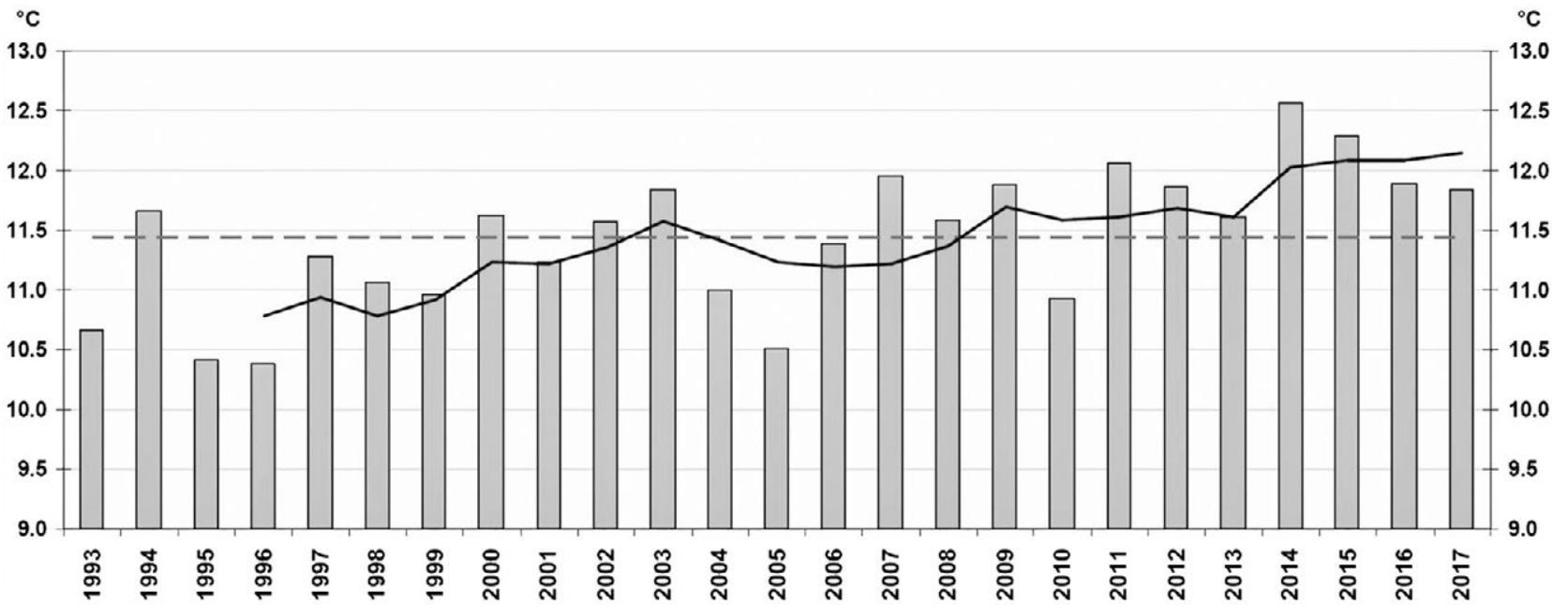

Fig. 7. - Veneto district mean air temperatures. Weighted averages of 134 thermometric stations operating in Veneto for the period 19932017. The solid line represents the four-year moving average. The dashed line represents the mean for the entire period (from Dell' Acqua et al. 2017, modified).

Increasing water transparency in the period 19982007 has been attributed to declining river discharge into the LoV (Bernardi Aubry et al. 2013). More recently (2011-2014), the reduction in clam farming and the resurgence of macroalgae and seagrasses have also been cited as causes (Sfriso et al. 2019). The overall increase in transparency during the period considered in this study is shown in Tables 2 and 3.

Mean relative oxygen increased significantly and since 2012 has never fallen below 110\%, although these levels are still way below those observed in the late 1980s and early 1990s. Indeed, that period saw average saturation levels of up to $250 \%$ in the central (Sfriso et al. 2019) and northern lagoons (Bianchi et al. 2000) due to the massive development of macro- and microalgae.

The biggest changes in nutrients over the years have been found in ammonium, concentrations of which have decreased significantly since 2007 . What we observed is in agreement with trends in the LoV reported for the first few years of the $21^{\text {st }}$ century by Harleman (2005), Solidoro et al. (2010) and Bernardi Aubry et al. (2013). Specifically, Sfriso and Buosi (2018) showed that ammonium levels in the waters around the industrial zone of Porto Marghera fell by two orders of magnitude over a fifty-year period (1962-1964, 3800 $\mu \mathrm{M} ; 1970-1972,1200 \mu \mathrm{M} ; 1976-1977,200 \mu \mathrm{M} ; 2011$, 10-20 $\mu \mathrm{M})$. Nitrates also fell, although not to the same degree as ammonium. This fall can be attributed at least partly to the effects of Council Directive 91/676/ EC, which provides the identification of "Nitrate Vulnerable Zones" in which the prohibition of spreading farm waste was introduced beyond a maximum limit of $170 \mathrm{~kg}$ nitrogen/hectare/year and established codes of good agricultural practice to be adopted by farmers. The directive was implemented by the subsequent Italian legislation through Legislative Decree no. 152 of 11 May 1999 and the Ministry Decree of 7 April 2006. The fall in ammonium and nitrate concentrations explained the significant decline in dissolved inorganic nitrogen levels detected by the present study (Table 2) and other authors (Bernardi Aubry et al. 2013, Sfriso and Buosi 2018). In the late 1980s, phosphorus concentrations fell sharply as a result of the ban on the use of phosphorus in detergents. Our data, which run from 1998, show that phosphates have continued to decline, albeit not significantly (Table 2). As in other lagoons, the N/P ratio has become much higher in the LoV than the canonical 16:1 (Pérez-Ruzafa et al. 2019): in the last three years of this study (2015-2017) it varied between 50 and 70, while in previous years (1998-2014) it was always above 100; its decrease is the result of the significant decrease in nitrogen inputs.

The decline of nutrients in lagoon waters does not appear to be linked to a decrease in rainfall and river discharge over the period studied (Fig. 3). In fact, the analysis of the rainfall time series recorded by 17 meteorological stations located in the drainage basin of the lagoon did not highlight any significant trend (Table 2).

In the study area, concentrations of chlorophyll $a$ decreased significantly during the period 1998-2017, remaining below $10 \mu \mathrm{g} \mathrm{L} \mathrm{L}^{-1}$ except in the year 2001 . This decrease could be linked to both the decrease in nitrogen inputs and the competition for nutrients between phytoplankton and the other primary producers (macroalgae and seagrasses) that have recolonized the lagoon in recent years. This recolonization has been so significant that it can even be detected by satellite, as seen in the maps of macrophyte cover in the sampling area in spring 1998, 1999, 2016 and 2017 (Fig. 6). In the first two years (1998 and 1999) the coverage was very poor, while in the last two years the sampling stations and/or neighbouring areas show dense coverage. The marked presence of these primary producers may explain the increase in dissolved oxygen in recent years, together with the significant reduction in phytoplankton biomass and increased transparency.

The seasonal Kendall- $\tau$ test revealed significant temporal trends for some parameters (Table 2). Further statistical analysis performed using the regime shift method enabled us to observe that for temperature, transparency, dissolved oxygen and ammonium the 
change was abrupt, while the other parameters showing significant $\tau$ changed more gradually. For transparency and oxygen, the shift was influenced by the recolonization of the lagoon by macroalgae and seagrasses in recent years. The temperature shift after 2011 was corroborated by the average annual air temperature in the Veneto district, which in the period 2011-2017 was always above $11.5^{\circ} \mathrm{C}$, the average for the last 25 years (Dell' Acqua 2017, Fig. 7). Both the reduced and the oxidized forms of nitrogen decreased in the period considered, though the decrease in ammonium was more abrupt than that in nitrates. Overall, the decrease in dissolved inorganic nitrogen was most affected by the gradual decrease in its oxidized form. All these shifts need to be verified in the long term in order to understand whether they are exceptional or reveal a new regime.

\section{CONCLUSIONS}

The last few decades have seen substantial changes in the LoV's morphological and hydrodynamic characteristics, together with significant variations in the amounts of pollutants and nutrients entering its waters (Solidoro et al. 2010, Bernardi Aubry et al. 2013, Sfriso et al. 2019). In the 1970s and 80s, when nutrient loads were at their highest, there was huge growth of Ulvaceae, and phytoplankton blooms were frequent, especially in the central basin, accompanied by a decline in seagrasses. Macroalgae remained dominant until the early 1990s and then began to fall. Thus, by the time the data series referred to this study began, Ulvaceae biomass had already peaked. At first (19972000), phytoplankton were still abundant, microalgal blooms were frequent and the presence of macroalgae and seagrasses in the sampling areas was limited. In subsequent years, there was a decrease in phytoplankton abundance and bloom frequency while macrophyte biomass increased. The actions promoted by the laws to limit the impacts caused by the supply of eutrophying substances (e.g. the Ronchi-Costa Decree of 23 April 1998 setting limits on the discharge of total nitrogen and total phosphorus at $10 \mu \mathrm{g} \mathrm{L}^{-1}$ and $1 \mu \mathrm{g} \mathrm{L}-1$, respectively, and the Ministry Decree of 2 February 1999 setting the maximum annual allowable nutrient loads at $3000 \mathrm{t}$ for total nitrogen and $300 \mathrm{t}$ for total phosphorus) caused nutrient levels in lagoon waters to decline and hypo- and hyperoxia to become less frequent, although there was a brief and limited hypoxia event in July 2013 that caused fish mortality (Bastianini et al. 2013).

Our data thus highlight an improvement in the ecological condition of the LoV, as also evidenced by the monitoring of biological elements in accordance with the Water Framework Directive 2000/60/EC (Regione Veneto et al. 2015). It is important to monitor the increasing temperature of the LoV's water in response to climate change, since this is likely to impact dissolved oxygen concentrations, lagoon organism physiology and the timing of lagoon processes (Pérez-Ruzafa et al. 2019). Furthermore, the construction and functioning of MOSE, the system of gates designed to close the seaward inlets during exceptionally high tides in order to protect Venice from flooding, is expected to modify the exchanges and fluxes of waters, nutrients and suspended matter between the lagoon and the sea, consequently affecting primary producers and upper trophic levels. Maintenance of this temporal data series, combined with the use of satellite maps, will be a useful tool for evaluating future changes to the LoV ecosystem.

\section{ACKNOWLEDGEMENTS}

The LoV belongs to the LTER-Italy, LTER-Europe and LTER-International Long-Term Ecological Research networks: the time series analysed in this paper was gathered in the context of these networks. The authors wish to thank F. Bianchi, E. Camatti, S. Finotto, M. Pansera and L. Dametto for their technical support during sampling and other fieldwork and the crew of the M/B Litus, G. Zennaro, D. Penzo, and M. Penzo. Furthermore, the authors wish to thank two anonymous referees as well A. Pugnetti and Lina Rodriguez Valdes, who provided constructive comments that helped to improve the manuscript. Landsat data were obtained from the US Geological Survey - Earth Resources Observation and Science (EROS) Center. M. Zasso (Regione Veneto-ARPAV, Agency for the Protection of the Veneto Environment) provided river discharge data.

This work was partially supported by funding from the EC programme 'LIFE-WATERS' (1997-2000) and from the second Consortium for Coordination of Research Activities Concerning the Venice Lagoon System (CORILA) research programme (2004-2007).

\section{REFERENCES}

Acri F., Bernardi Aubry F., Bianchi F., et al. 2004. Plankton communities and nutrients in the Venice lagoon: Comparison between current and old data. J. Mar. Syst. 51: 321-329. https://doi.org/10.1016/j.jmarsys.2004.05.019

Alberighi L., Bianchi F., Cioce F., et al. 1992. Osservazioni durante un bloom di Skeletonema costatum in prossimità della centrale termoelettrica ENEL di Fusina Porto-Marghera (Venezia). Oebalia 17 (Suppl.): 321-322

Amos C.L., Umgiesser G., Ghezzo M. et al. 2017. Sea surface temperature trends in Venice Lagoon and the adjacent waters. J. Coast. Res. 33: 385-395.

https://doi.org/10.2112/JCOASTRES-D-16-00017.1

Bastianini M., Bernardi Aubry F., Acri F., et al. 2013. The Redentore fish die-off in the Lagoon of Venice: an integrated view. Società Botanica Italiana, Gruppo di Algologia, Riunione Scientifica Annuale, Venezia, 18-19 ottobre, 32 pp.

Bernardi Aubry F., Acri F., Bianchi F., et al. 2013. Looking for patterns in the phytoplankton community of the Mediterranean microtidal Venice Lagoon: evidence from ten years of observations. Sci. Mar. 77: 47-60. https://doi.org/10.3989/scimar.03638.21A

Bertoni R. 2012. The Italian network for long-term ecological research (lter - Italy) situation and prospects after five years of activity (2006-2011). Aracne Editrice, Roma, 232 pp. [in Italian] http://www.ise.cnr.it/crypta/ebooks/La\% 20 rete\% 20 italiana\%20LTER.pd

Bianchi F., Acri F., Alberighi L., et al. 2000. Biological variability in the Venice Lagoon. In: Lasserre P., Marzollo A. (eds), The Venice Lagoon Ecosystem. Inputs and Interactions between Land and Sea. UNESCO and Parthenon Publishing Press, pp. 97-126.

Bianchi F., Acri F., Bernardi Aubry F., et al. 2003. Can plankton communities be considered as bio-indicators of water quality in the Lagoon of Venice? Mar. Pollut. Bull. 46: 964-971. 
https://doi.org/10.1016/S0025-326X(03)00111-5

Borja A. 2005. The European Water Framework Directive: a challenge for nearshore, coastal and continental shelf research. Cont. Shelf. Res. 25: 1768-1783. https://doi.org/10.1016/j.csr.2005.05.004

Boyer J.N., Fourqurean J.W., Jones R.D. 1999. Seasonal and LongTerm Trends in the Water Quality of Florida Bay (1989-1997). Estuaries 22: 417-430. https://doi.org/10.2307/1353208

Coull B.C. 1985. The use of long-term biological data to generate testable hypotheses. Estuaries 8: 84-92. https://doi.org/10.2307/1351859

Cucco A., Umgiesser G. 2006. Modeling the Venice Lagoon residence time. Ecol. Model.193: 34-51. https://doi.org/10.1016/i.ecolmodel.2005.07.043

Dell'Acqua N., Terrabujo C., Luchetta A., et al. 2017. About climate change. Agenzia Regionale per la Prevenzione e Protezione Ambientale del Veneto, 28 pp. [In Italian]

European Union. 2000. Directive 2000/60/EC of the European Parliament and of the Council of 23 October 2000 establishing a framework for Community action in the field of water policy. Official Journal L 327.

Franklin J.F. 1989. Importance and justification of long-term studies in ecology. In: Likens G.E. (eds), Long-Term Studies in Ecology. Springer, New York, pp. 3-19. https://doi.org/10.1007/978-1-4615-7358-6 1

Ghezzo M., De Pascalis F., Umgiesser G., et al. 2015. Connectivity in three European coastal lagoons. Est. Coasts 38: 1764-1781. https://doi.org/10.1007/s12237-014-9908-0

Ghirardi N., Bolpagni R., Bresciani M., et al. 2019. Spatiotemporal dynamics of submerged aquatic vegetation in a deep lake from Sentinel-2 Data. Water 11: 563 https://doi.org/10.3390/w11030563

Giardino C., Candiani G., Bresciani M., et al. 2012. BOMBER: A tool for estimating water quality and bottom properties from remote sensing images. Comput. Geosci. 45: 313-318. https://doi.org/10.1016/j.cageo.2011.11.022

Giardino C., Bresciani M., Cazzaniga I., et al. 2014. Evaluation of multi-resolution satellite sensors for assessing water quality and bottom depth of Lake Garda. Sensors 14: 24116-24131. https://doi.org/10.3390/s141224116

Grasshoff K., Ehrhardt M., Kremling K. (eds). 1983. Methods of Seawater Analysis. Second, Revised and Extended Edition. Wiley-VCH Verlag, pp. 419 https://doi.org/10.1002/iroh.19850700232

Haase P., Frenzel M., Klotz S, et al. 2016.The long-term ecological research (LTER) network: relevance, current status, future perspective and examples from marine, freshwater and terrestrial long-term observation. Ecol. Indic. 65: 1-3. https://doi.org/10.1016/j.ecolind.2016.01.040

Haase P., Tonkin J.D., Stoll S., et al. 2018. The next generation of site-based long-term ecological monitoring: linking essential biodiversity variables and ecosystem integrity. Sci. Total Environ. 613-614: 1376-1384. https://doi.org/10.1016/j.scitotenv.2017.08.111

Harleman D.R.F. 2005. Mobile barriers as a management tool for water quality and lagoon flushing. In: Fletcher C.A., Spencer T. (eds). Flooding and environmental challenges for Venice and its Lagoon: state of knowledge. Cambridge University Press, pp. 279-286.

Hirsch R.M., Alexander R.B., Smith R.A. 1991. Selection of methods for the detection and estimation of trends in water quality. Water Resour. Res. 27: 803-813. https://doi.org/10.1029/91WR00259

Holm-Hansen O., Lorenzen C.J., Holmes R.W., et al. 1965. Fluorometric determination of chlorophyll. ICES J. Mar. Sci. 30: 3-15. https://doi.org/10.1093/icesjms/30.1.3

Mirtl M., Borer E., Djukic I., et al. 2018. Genesis, goals and achievements of Long-Term Ecological Research at the global scale: A critical review of ILTER and future directions. Sci. Total Environ. 626: 1439-1462. https://doi.org/10.1016/j.scitotenv.2017.12.001

Pérez-Ruzafa A., Campillo S., Fernández-Palacios J.M., et al. 2019. Long-Term Dynamic in Nutrients, Chlorophyll $a$, and Water
Quality Parameters in a Coastal Lagoon During a Process of Eutrophication for Decades, a Sudden Break and a Relatively Rapid Recovery. Front. Mar. Sci. 6: 26 https://doi.org/10.3389/fmars.2019.00026

Poggioli S. 2008. MOSE Project Aims to Part Venice Floods. Morning Edition. NPR. 7 January 2008 (Radio Podcast). https://www.npr.org/templates/story/story.php?storyId=17855145

Regione Veneto, ARPAV, CORILA. 2015. Monitoring plan of the Venice lagoon aimed at the definition of the ecological status under Directive 2000/60/EC (Legislative decree N. 152/2006 s.m.i.). 2nd monitoring cycle, period 2013-2015. EQB: Macrophyte. Final Report: 1-33. [in Italian]

Rodionov S.N. 2004. A sequential algorithm for testing climate regime shifts. Geophys. Res. Lett. 31: L09204. https://doi.org/10.1029/2004GL019448

Sen P.K. 1968. Estimates of the Regression Coefficient Based on Kendall's Tau. J. Am. Stat. Assoc. 63: 1379-1389. https://doi.org/10.1080/01621459.1968.10480934

Sfriso A., Buosi A. 2018. Trophic status changes in the Venice Lagoon during the last 40 years. Convegno: $49^{\circ}$ Congresso SIBM, Genova, 4-8 Giugno, pp. 36-39.

Sfriso A., Facca C., Ceoldo S., et al. 2005. Recording the occurrence of trophic level changes in the lagoon of Venice over the ' $90 \mathrm{~s}$. Environ. Int. 31: 993-1001 https://doi.org/10.1016/j.envint.2005.05.009

Sfriso A., Buosi A., Mistri M., et al. 2019. Long-term changes of the trophic status in transitional ecosystems of the northern Adriatic Sea, key parameters and future expectations: the lagoon of Venice as a study case. Nat. Conserv. 34: 193-215. https://doi.org/10.3897/natureconservation.34.30473

Socal G., Bianchi F., Alberighi L. 1999. Effects of thermal pollution and nutrient discharges on a spring phytoplankton bloom in the industrial area of the lagoon of Venice. Vie Milieu 49: 19-31.

Solidoro C., Pastres R., Cossarini G., et al. 2004. Seasonal and spatial variability of water quality parameters in the lagoon of Venice. J. Mar. Syst. 51: 7-18. https://doi.org/10.1016/j.jmarsys.2004.05.024

Solidoro C., Bandelj V., Bernardi Aubry F., et al. 2010. Response of the Venice lagoon ecosystem to natural and anthropogenic pressures over the past 50 years. In: Kennish M.J., Paerl H.W. (eds), Coastal lagoons - Critical habitats of environmental change. CRC Press. Boca Raton, pp. 483-511. https://doi.org/10.1201/EBK1420088304

Strickland J.D.H., Parsons T.R., et al. 1972. A practical handbook of seawater analysis. J. Fish. Res. Board Can. 167: 1-310

Tagliapietra D., Aloui Bejaoui N., Bellafiore D., et al. 2011. The ecological implications of climate change on the Lagoon of Venice. UNESCO, 48 pp.

Theil H. 1950.A Rank Invariant Method of Linear and Polynomial Regression Analysis, i, ii, iii. Proceedings of the Koninklijke Nederlandse Akademie Wetenschappen, Series A Mathematical Sciences. 53: 386-392, 521-525, 1397-1412.

Umgiesser G., Ferrarin C., Cucco A., et al. 2014. Comparative hydrodynamics of 10 Mediterranean lagoons by means of numerical modeling. J. Geophys. Res. C 38: 1764-1781. https://doi.org/10.1002/2013JC009512

University of Southampton. 2012. Venice Lagoon research indicates rapid climate change in coastal regions. ScienceDaily, 28 September 2012. https://www sciencedaily com/releases/2012/09/120928125306.htm

Wolfe D.A., Champ M.A., Flemer D.A., et al. 1987. Long-Term biological data sets: their role in research, monitoring, and management of estuarine and coastal marine systems. Estuaries 10: 181-193. https://doi.org/10.2307/1351847

Zhang J., Wu L. 2015. Modulation of the urban heat island by the tourism during the Chinese New Year holiday: a case study in Sanya City, Hainan Province of China. Sci. Bull. 60: 1543-1546. https://doi.org/10.1007/s11434-015-0864-2

Zirino A., Elwany H., Neira C., et al. 2014. Salinity and its variability in the Lagoon of Venice, 2000-2009. Adv. Oceanogr. Limnol. 5: 41-59. https://doi.org/10.1080/19475721.2014.900113 